\title{
Effect of cell-bound hyaluronic acid on infectivity of Newcastle disease virus for human synovial cells in vitro
}

\author{
B. J. CLARRIS, J. R. E. FRASER, AND S. J. RODDA \\ From the Departments of Medicine and Microbiology, University of Melbourne, Australia
}

The possible involvement of viruses in the pathogenesis of rheumatoid arthritis has been debated for some years. Recently, interest was quickened by reports that rheumatoid synovial cells in vitro, in contrast with non-rheumatoid synovial cells, were completely resistant to rubella virus (Grayzel and Beck, 1970) and relatively resistant to Newcastle disease virus (Smith and Hamerman, 1968). However, this apparent resistance to superinfection has not been confirmed with rubella (Person, Rawls and Sharp, 1971; Ford, 1972; Parker, McCollum and Kerby, 1972; Runge and Allison, 1972; Spruance, Smith, Krall, and Ward, 1972) or with Newcastle disease virus (Person and others, 1971; Spruance and others, 1972).

The disagreement in these studies is not easily explained. However, in planning a similar study following the first reports, the authors decided to take into account another factor which could cause a random or systematic difference in susceptibility of cells to virus infections. Synovial cells are invested in culture with thick cohesive gels of hyaluronic acid (Clarris and Fraser, 1968a). This might conceivably interfere with initial adsorption and uptake of virus; it has already bzen found to modify the responses of the cells to homologous serum (Clarris and Fraser, 1968b) and lymphocytes (Fraser and Clarris, 1970), and to influence infection with Chlamydia (Clarris, Fraser, and Harrison, unpublished).

The present study was therefore designed to test the hypothesis that the pericellular hyaluronic acid of human synovial cells can interfere with infection by virus. Newcastle disease virus (NDV) was chosen because its production by individual cells can be readily detected by haemadsorption. Both rheumatoid and non-rheumatoid cell strains were examined.

\section{Material and methods}

CELL-STRAINS

Methods of isolation and maintenance of human synovial cells have been described (Clarris and Fraser, 1967). In the present study, strains were obtained from rheumatoid and non-rheumatoid subjects, and used only in the diploid phase of growth (Clarris and Fraser, 1968c).

NEWCASTLE DISEASE VIRUS

This was an avirulent strain (V-8) VRI/66, isolated at the Veterinary Research Institute, Melbourne. The virus was grown in the allantois of 10-day-old chick embryos, and titrated by the in vitro allantois-on-shell method of Fazekas de St. Groth and White (1958), the infectivity titre being calculated in terms of ' 50 per cent. infectious doses' (ID 50 ).

\section{HYALURONIDASE}

Solutions of bacterial enzyme (specific activity: 18,320 i.u. per mg.) were prepared in Dulbecco-Vogt phosphate-

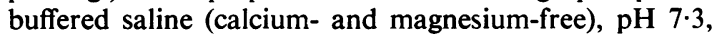
with 1 per cent. heat-inactivated $\left(56^{\circ} \mathrm{C}\right.$ for $30 \mathrm{~min}$.) foetal calf serum. Enzyme activity was confirmed by mucin-clot inhibition (Robertson, Ropes, and Bauer, 1940) in bovine synovial fluid. Final concentration was 80 units per ml. of culture medium in all experiments.

EXPERIMENTAL DESIGN

The establishment of replicate synovial cultures and measurement of cell numbers has been described previously (Clarris and Fraser, 1967). The order of individual cultures and allotment to treatment groups were randomized. Cultures were rinsed with Hanks's balanced salt solution (BSS) and incubated with enzyme solution or diluent for $1-2 \mathrm{hr}$ at $37^{\circ} \mathrm{C}$. After further rinsing with BSS, the chosen dose of virus in $1 \mathrm{ml}$. BSS was allowed to adsorb to the cell layers for $1 \mathrm{hr}$ at $37^{\circ} \mathrm{C}$. With the stated exceptions, the cultures were rinsed again and incubated for $18 \mathrm{hrs}$ at $37^{\circ} \mathrm{C}$. in medium 199 containing 5 per cent. $(\mathrm{v} / \mathrm{v})$ heat-inactivated young calf serum.

\section{DETECTION OF INFECTIONS}

A haemadsorption technique similar to that of Smith and Hamerman (1968) was used. After rinsing with BSS, $1 \mathrm{ml}$. fowl erythrocytes (5 per cent. in BSS) was added to each culture for 15 to $20 \mathrm{~min}$. at $4^{\circ} \mathrm{C}$. Unabsorbed erythrocytes were then removed by rinsing, and the cultures examined by phase-contrast microscopy. Synovial cells bearing one or more attached erythrocytes were counted as infected. The fifty fields examined in each flask were selected systematically from the culture surface. All flasks were coded to be unidentifiable by the observer. 
Results

Infection by NDV was first compared in hyaluronidase-treated and control cultures inoculated with $0 \cdot 1$ ID $_{50}$ per cell (Table I). In all cases, a higher proportion of cells was infected in the enzyme-treated cultures. Some of the differences were small and not statistically significant in themselves, but the net effect of treatment was highly significant in both series.

Further experiments were undertaken to determine whether the enzyme treatment genuinely enhanced the susceptibility of the cells to virus infection, or merely facilitated the phenomenon of haemadsorption (Table II).

The proportion of infected cells in cultures treated with hyaluronidase before inoculation was more than twice that in untreated cultures, and none of the readings was altered by enzyme treatment immediately before haemadsorption ( $c f$. $\mathrm{A}$ and $\mathrm{B}$ with $\mathrm{E}$ and F). This conclusion is reinforced by the identity of $\mathrm{C}$ and $\mathrm{D}$. Thus the observed effects of hyaluronidase are attributable to an increase in the susceptibility of the cells to infection.

\section{Discussion}

Treatment with hyaluronidase, previously shown to remove pericellular hyaluronic acid, clearly enhanced the susceptibility of human synovial cell cultures to NDV. This effect was equally evident for rheumatoid and non-rheumatoid lines. No difference in susceptibility was demonstrable between rheumatoid and non-rheumatoid lines, with or without enzyme treatment.

In contrast with the effect on initiation of infection, hyaluronidase had no direct influence on haemadsorption in previously treated or untreated cultures. Since pericellular hyaluronic acid prevents contact of erythrocytes with the synovial cell surface in culture, virus infection of these cells must cause dissolution of the gels; otherwise, virions or newly-synthesized virus haemagglutinin must extend sufficiently far through the gel matrix to allow haemadsorption to occur. Virus haemagglutinin is known to project as visible 'spikes' from the plasma membrane of cells from which virions are budding (Compans, Holmes, Dales, and Choppin, 1966).

Table I Effect of hyaluronidase on infection of human synovial cell-lines by Newcastle disease virus

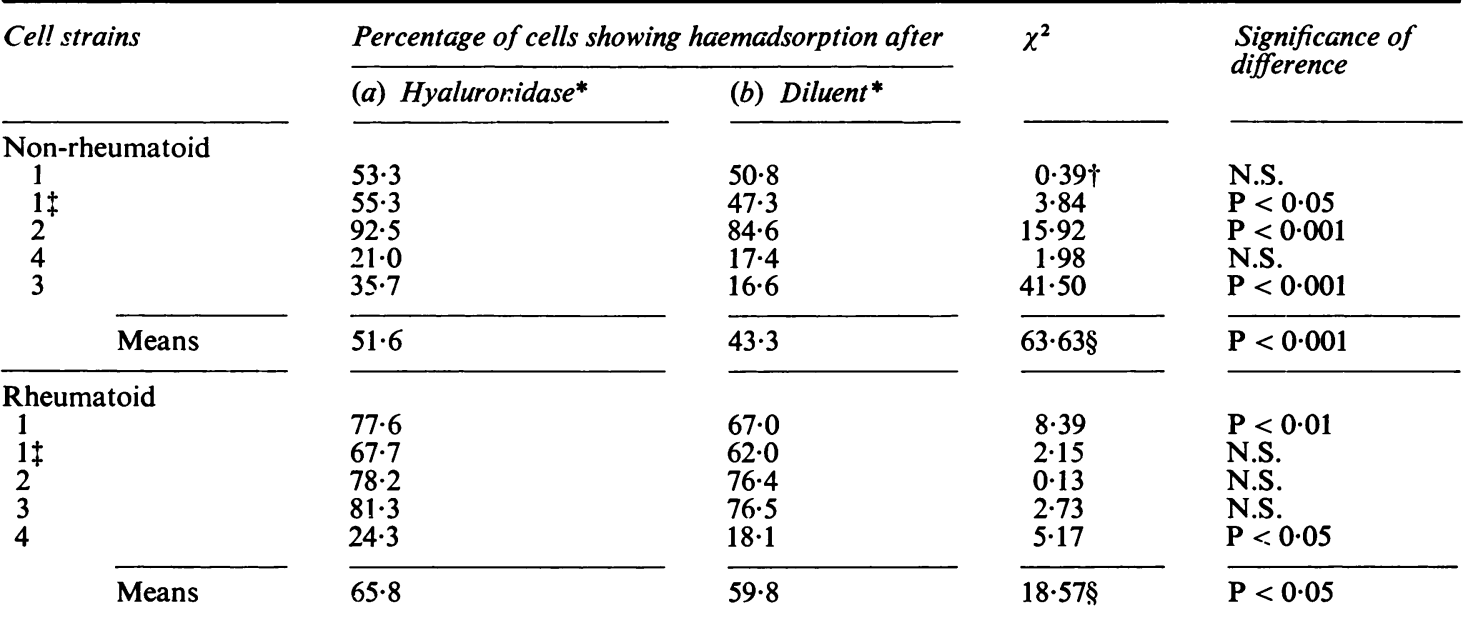

* Treatment as described in Methods.

$\dagger \chi^{2}$ tests with Yates's correction.

$\mp$ Inoculum of virus left in cultures throughout $18 \mathrm{hrs}$ ' incubation. $\$$ Summation according to Snedecor and Cochran (1967).

Table II Mode of action of hyaluronidase in Newcastle disease virus infection of synovial cells

\begin{tabular}{|c|c|c|c|c|}
\hline $\begin{array}{l}\text { Treatment before } \\
\text { infection }\end{array}$ & $\begin{array}{l}\text { Treatment before } \\
\text { haemadsorption }\end{array}$ & $\begin{array}{l}\text { Percentage of cells } \\
\text { showing } \\
\text { haemadsorption }\end{array}$ & $\chi^{2}$ & $\begin{array}{l}\text { Significance of } \\
\text { difference }\end{array}$ \\
\hline $\begin{array}{l}\text { A. Hyaluronidase } \\
\text { B. Diluent }\end{array}$ & - & $\begin{array}{l}35 \cdot 7 \\
16 \cdot 6\end{array}$ & $41 \cdot 5$ & $P<0.001$ \\
\hline $\begin{array}{l}\text { C. - } \\
\text { D. - }\end{array}$ & $\begin{array}{l}\text { Hyaluronidase } \\
\text { Diluent }\end{array}$ & $\begin{array}{l}18 \cdot 9 \\
20 \cdot 4\end{array}$ & 0.31 & N.S. \\
\hline $\begin{array}{l}\text { E. Hyaluronidase } \\
\text { F. Diluent }\end{array}$ & $\begin{array}{l}\text { Hylauronidase } \\
\text { Hylauronidase }\end{array}$ & $\begin{array}{l}20 \cdot 4 \\
40 \cdot 2 \\
18 \cdot 7\end{array}$ & $69 \cdot 9$ & $P<0.001$ \\
\hline
\end{tabular}


No doubt the increase in susceptibility of synovial cells after hyaluronidase treatment is a direct consequence of an increase in the accessibility of the glycoprotein receptors in the plasma membrane which comprise the specific attachment sites for orthomyxoviruses and paramyxoviruses (Hirst, 1965). Much work has been done on virus infectivity in relation to glycosaminoglycans, and other polysaccharides either naturally or synthetically substituted with ionizable radicals. This has been largely concerned with exogenous material and with interactions in the liquid phase of test cultures (Takemoto and Fabisch, 1964) or in agar overlays for plaque assays of virus (Takemoto and Spicer, 1965), where hyaluronic acid has had little effect compared with polycations or more densely anionic polysaccharides (Colter and Campbell, 1965).

Cell-bound hyaluronic acid occurs as a dense gel rather than a sol, and hence would be expected to impede the access of virions to the plasma membrane. Any significant diminution in the rate of diffusion of virions through such a gel could substantially delay the initiation of infection, or abort it altogether by lengthening the time of exposure of these labile viruses to inactivation by heat or inhibitory factors in the medium.

\section{Summary}

Cell strains derived from human synovium were exposed to infection by the paramyxovirus of Newcastle disease. No significant difference was detected in the susceptibility of rheumatoid and non-rheumatoid lines.

Prior treatment of the cells with hyaluronidase enhanced the susceptibility of both cell-types to virus infection. It is concluded that cell-bound hyaluronic acid interferes with the adsorption of virus to synovial cells.

We are grateful to Prof. D. O. White for advice and encouragement; to Mr. Kingsley Mills for rheumatoid synovial tissue; and to N. V. Organon, Oss, Holland, for hyaluronidase. This work was supported by grants from the National Health and Medical Research Council.

\section{References}

Clarris, B. J., and Fraser, J. R. E. (1967) Aust. J. exp. Biol. Med. Sci., 45, 549 (The effects of homologous and heterologous whole serum upon multiplication of recently-isolated human synovial cells in culture)

__ - (1968a) Exp. Cell Res., 49, 181 (On the pericellular zone of some mammalian cells in vitro)

_- (1968b) Aust. J. exp. Biol.Med. Sci., 46, 107 (Some factors influencing the reactions of human synovial cells in vitro with fresh homologous and autologous serum)

- - (1968c) Ann. rheum. Dis., 27, 597 (Relationship between chromosomal changes and alterations in the behaviour of a strain of human synovial cells during its life history in vitro)

Colter, J. S., ANd Campbell, J. B. (1965) Ann. N.Y. Acad. Sci., 130, 383 (The effect of polyanions and polycations on Mengo virus- $\mathrm{L}$ cell interaction)

Compans, R. W., Holmes, K. V., Dales, S., and Choppin, P. W. (1966) Virology, 30, 411 (An electron microscopic study of moderate and virulent virus-cell interactions of the parainfluenza virus SV5)

Fazekas de St. Groth, S., AND White, D. O. (1958) J. Hyg. (Camb.), 56, 151 (An improved assay for the infectivity of influenza viruses)

FORD, D. K. (1972) Arthr. and Rheum., 15, 313 (Noncytopathogenicity of rubella vaccine Strain HPV-77 for synovial cells)

Fraser, J. R. E., AND Clarris, B. J. (1970) Clin. exp. Immunol., 6, 211 (On the reactions of human synovial cells exposed to homologous leucocytes in vitro)

GRAYZEL, A. I., AND BECK, C. (1970) J. exp. Med., 131, 367 (Rubella infection of synovial cells and the resistance of cells derived from patients with rheumatoid arthritis)

HIRST, G. K. (1965) 'Cell-virus attachment and the action of antibodies on viruses' in 'Viral and Rickettsial Infections of Man', ed. F. L. Horsfall and I. Tamm, 4th ed., p. 216. Lippincott, Philadelphia

Parker, M. D., McCollum, D. E., AND Kerby, G. P. (1972) Arthr. and Rheum., 15, 275 (Susceptibility of cultures of rheumatoid tissues to rubella virus infection)

Person, D. A., Rawls, W. E., ANd Sharp, J. T. (1971) Proc. Soc. exp. Biol. (N.Y.), 138, 748 (Replication of rubella, Newcastle Disease, and vesicular stomatitis viruses in cultured rheumatoid synovial cells)

Robertson, W. van B., Ropes, M. W., and Bauer, W. (1940) J. biol. Chem., 133, 261 (Mucinase: a bacterial enzyme which hydrolyzes synovial fluid mucin and other mucins)

Runge, L. A., AND Allison, A. C. (1972) Arthr. and Rheum., 15, 85 (Growth of rubella virus in cultures of synovial cells from rheumatoid arthritis)

Smith, C., AND Hamerman, D. (1968) Ibid., 11, 842 (Resistance of rheumatoid synovial cells to infection with exogenous virus)

SNEDECOR, G. W., AND COCHRAN, W. G. (1967) 'Attribute data with more than one degree of freedom' in 'Statistical Methods', 6th ed., p. 232. Iowa State University Press, Ames, Iowa, U.S.A.

Spruance, S. L., Smith, C. B., Krall, J., AND WARD, J. R. (1972) Infect. and Immunity, 6, 326 (Growth of Newcastle disease virus and rubella virus in rheumatoid and non-rheumatoid synovial cell cultures)

Takemoto, K. K., ANd Fabisch, P. (1964) Proc. Soc. exp. Biol. (N.Y.), 116, 140 (Inhibition of herpes virus by natural and synthetic acid polysaccharides)

AND SpICER, S. S. (1965) Ann. N.Y. Acad. Sci., 130, 365 (Effects of natural and synthetic sulfated polysaccharides on viruses and cells) 